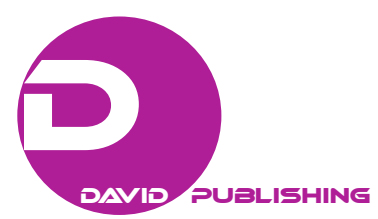

\title{
Fiscal Council and Pre-election Platforms Evaluation: A Scenario for Greece
}

\author{
Triantopoulos Christos, Chymis Athanasios \\ Centre of Planning and Economic Research, Athens, Greece
}

\begin{abstract}
The crisis of the Greek economy underlined the structural deficiency of the domestic growth model that was depicted to the wide "twin-deficit" problem of a statist market economy. The core of the domestic growth model is the role of the public sector which, inter alia, was characterized by high and permanent fiscal deficits, low efficiency, and steady divergence from an advanced welfare state. During the 2010-2015 adjustment effort, fiscal adjustment was the critical dimension of the effort in order to stabilize public finances at a sustainable level and significantly reduce the financial needs. The sustainability, however, of public finance stabilization is determined by the structural reforms in the fiscal policy framework and the public financial management framework. One of the structural fiscal reforms was the new law for the establishment of the Hellenic Fiscal Council in 2014 following the European institutional framework. The paper discusses the strong harmonization of electoral cycle and fiscal deterioration and analyses the scenario of enhancing the Fiscal Council's responsibilities in Greece with the evaluation of the pre-election platforms. In particular, the paper, taking into account the characteristics of the Greek political economy, focuses on the critical prerequisites so as this scenario to become a real structural reform. These institutional and political prerequisites are institutional independence, political independence, functional independence, broad political acceptance, "adjustment period", and clarity of rules and evaluation procedures. So, even though the evaluation of pre-election economic programs seems ultra-difficult for the case of Greece, it should not be set aside as unachievable in the long run.
\end{abstract}

Keywords: fiscal council, electoral cycle, fiscal discipline, adjustment, Greece

\section{Introduction}

The crisis of the Greek economy, following the global financial crisis of 2007/2008, highlighted in the most emphatic manner the structural deficiencies of the domestic growth model, as summarized in the huge "twin" deficits and debts that characterized the Greek economy up to 2009 (Pagoulatos \& Triantopoulos, 2009). The core of the growth model lies the strong state intervention, which was established in the 1980s, and which was gradually withdrawn during the route of the country towards the European integration and, in particular, during the country's accession to the Economic and Monetary Union (EMU) and thereafter. A key component, therefore, of the domestic model was - and to a large extent still is - the function of the public sector, which was characterized, inter alia, by low efficiency, a weak welfare state, and permanent fiscal deficits in the

Triantopoulos Christos, research fellow, Ph.D., Centre of Planning and Economic Research, Athens, Greece.

Chymis Athanasios, senior research fellow, Ph.D., Centre of Planning and Economic Research, Athens, Greece.

Correspondence concerning this article should be addressed to Triantopoulos Christos, Centre of Planning and Economic Research, Amerikis Str., 11, 10672, Athens, Greece. 
absence of substantial fiscal institutions and frameworks. These deficits were maintained after the introduction of the euro, due to the ability of the public sector to borrow from the international financial markets with relatively low cost. So, public debt increased, whilst the private sector, which was characterized by low competitiveness, moved also in the same direction of (relative) over-indebtedness (Pagoulatos, 2014). The global financial crisis of 2007/2008, however, and the shrinkage of international liquidity, combined with the diachronic "twin" deficits' problem of the Greek economy, and also with a range of policy decisions and changes, made the funding of the country from the international markets difficult, if not impossible. So, the country asked for funding from the "official" sector in 2010 and, in particular, from the newly established European Commission (EU)/European Central Bank (ECB)/International Monetary Fund (IMF) support mechanism.

The entrance to the EU/ECB/IMF support mechanism was accompanied by a fiscal and economic adjustment program, during which the country had - in limited time - to stabilize public finances, improve the robustness of the financial system, and strengthen the competitiveness of the economic activity and production. Thus, a series of reforms was launched in framework of public financial management during 2010-2014, aligned to the institutional changes in the EU and the euro area. The absence of strong institutions in the public financial management created enough "room" for the implementation of significant and widespread institutional interventions and reforms. One of the institutional reforms was the introduction in 2014 of the Hellenic Fiscal Council (hereinafter: Fiscal Council), which, however, although legislated was not established on time. In 2015, following the political developments, but also the requirements of the third economic adjustment program under the EU/ECB/IMF support mechanism, the establishment of the Fiscal Council re-entered to the public debate, enhanced this time with the scenario to take on the evaluation of the pre-election economic platforms of political parties.

After a period of strong and front-loaded fiscal consolidation and ultra-deep recession, it is critical for Greece to establish - along the EU framework - institutions that would guarantee fiscal stability and prevent a new turmoil in the future. Fiscal Council is such an innovative institution. The paper discusses the strong harmonization of electoral cycle and fiscal deterioration and analyses the scenario of enhancing the Fiscal Council's responsibilities in Greece with the evaluation of the pre-election platforms. In particular, the paper, taking into account the characteristics of the Greek political economy, discusses the critical prerequisites so as this scenario to become a real structural reform. On the one hand, the paper answers to the policy question about the way that the Fiscal Council could efficiently add its competences to the evaluation of the pre-election platforms by suggesting specific institutional steps that could protect, in the long run, the economy from the close relation of elections and fiscal instability. On the other hand, the analysis contributes to the broader debate on institution's building in economies with poor institutional tradition, like the Greek one.

The structure of the paper is the following. The second section focuses on the literature review and the theoretical background of the relevant discussion. The third section discusses the background and analyses the statist growth model of Greece up to the period of economic and fiscal adjustment, focusing on the field of public financial management as well. The fourth section focuses on the analysis of the institution of the Fiscal Council, emphasizing on the Greek case, while the fifth section deals with the under discussion scenario. Finally, the paper ends with some concluding remarks.

\section{Literature Review}


The analysis of the development of institutions within the economic and fiscal environment draws its theoretical background from the academic debate on the relation of institutions and economic activity. The debate about the importance of institutions in economic activity and, in general, in capitalism was strengthened during the analysis of the (different) ways (i.e. monetary policy, fiscal policy, etc.) some economies managed to cope with stagflation during the 1970s and on. The theoretical background is based on the new institutionalism approach, which is basically the evolution of institutionalism. New institutionalism approaches the role of institutions beyond traditional perspectives ${ }^{1}$ trying to explain, among other things, how institutions shape the behavior of actors and how economies with different growth paths led to convergent organizational structures (Lowndes, 2002; North, 2000; Kazakos, 2006). This context includes, also, institutional economics, which does not focus only on exploring the nature of economic institutions, but also emphasizes the way and the extent to which the economic and other institutions ${ }^{2}$ affect economic performance and economic activity both in the short and long term (Kazakos, 2006).

In terms of comparative political economy, the debate on the importance of institutions contributed to the development of the new corporatism approach (Schmitter \& Lehmbruch, 1979; Berger, 1981; Goldthorpe, 1984). New corporatism emphasized on the institutions that handle the dual problem of high inflation and persistently high unemployment. Thus, in contrast to previous approaches, ${ }^{3}$ new corporatism focused on labor contracts and negotiation framework, trade unions, and central banks, as these institutions have achieved with appropriate "compromises" (the first two) and with adequate monetary policy (the latter) to face the stagflation problem (Jackson \& Deeg, 2006; Triantopoulos, 2014). Gradually, therefore, the role ${ }^{4}$ of institutions gained great importance in the framework of comparative analysis regarding the evolution and structure of models of capitalism. So, institutions began to matter-according to the institutionalism - as they provide the scope within which economic activities, political debates, and individual or group strategies are developed, setting the standards and affecting the result of the interaction of actors (North, 2000; Kazakos, 2006).

In this context, putting the emphasis on the role of institutions and building on the previous approaches, the varieties of capitalism approach was developed (Hall \& Soskice, 2001). ${ }^{5}$ The analysis of the varieties of capitalism approach is based on two basic models, those of the coordinated market economy and the liberal market economy, whilst it extended to a third variety, the statist market economy. The third variety is focused on the role of the state, which is significantly involved in the coordination between the actors of the economy, replacing the absence of institutions that would promote strategic coordination (Schmidt, 2002; 2003; Molina \& Rhodes, 2007; Hancke, Rhodes, \& Thatcher, 2007). Thus, the gradual withdrawal of the involvement of the state in various fields of economic activity, combined with the absence of pre-existing institutions for strategic coordination, enriches the variety with liberal features, leading to a model of mixed market economy (i.e.

\footnotetext{
${ }^{1}$ In particular, emphasis is given on the rules, the informal institutions, the dynamic analysis, and on examining individual components of the political and economic environment.

2 Other institutions are politicians, unions (employees' unions, productive entities, professional associations, etc.), social institutions, etc.

${ }^{3}$ Previous approaches placed the focus of their analysis on the role of the state (Shonfield, 1965), the organizational structure of corporations (Chandler, 1977) and the organization of the production process (Zysman, 1983).

${ }_{5}$ The institutions could be either bodies or rules or procedures.

5 The approach of capitalist organization models initially distinguishes two basic models: (a) the coordinated market economy model, where economic and development activity-having business to its core-is based on strategic coordination through institutional frameworks and processes, between "stakeholders" and key actors (i.e. Anglo-Saxon economies), and (b) the liberal market economy model, where the coordination is based on market forces under a corresponding institutional environment (i.e. continental European economies).
} 
Southern European economies) (Hall \& Gingerich, 2004; Pagoulatos \& Triantopoulos, 2014).

In terms of case study analysis, the theoretical discussion about the lack of adequate institutions in an economy and, particularly, in a field of economics such as public finance, may be based on the public choice theory. According to the public choice approach, governments, bureaucracies, and interest groups consist of individuals who behave exactly like the actors in the private sector, constantly seeking to maximize their net benefit. In the case, therefore, of a political member of a democratically elected government, the net benefit is translated into re-election and the ability to manage public funds (Kroszner \& Strahan, 2000), turning, as Kazakos (2006) has notably highlighted, the homo politicus into a homo economics in a political market. In such a market, according to Buchanan (1987), politics “(...) is a structure of complex exchange among individuals, a structure within which persons seek to secure collectively their own privately defined objectives that cannot be efficiently secured through simple market exchanges (...)”. Thus, the political system becomes quite reluctant in promoting strict institutions in fiscal management, which would limit the possibility of maximizing its short-term net benefit. And thus, the larger the size and the role of the public sector, as identified in the statist (or mixed) market economy model, the higher the stakes and the cost for the political system is regarding the promotion of institutions that would significantly limit the benefits that could derive from public financial management.

The inability to establish a fiscal discipline environment, as set out by Rapanos and Kaplanoglou (2010), can theoretically be explained by (a) the phenomenon of "common pool", under which the pressure of small-sized but large in unionistic or political power interest groups leads to high public expenditure in favor of these groups, while these specific groups pay only a small part of the tax revenues that correspond to these costs, (b) the phenomenon of "myopic logic" in the exercise of fiscal policy due to the mismatch of the time horizon of government policy compared to the needs of society and the economy, and (c) the phenomenon of lack of necessary knowledge and information from both the political personnel and citizens in order to adequately assess fiscal policy. ${ }^{6}$ The inability, therefore, is to establish fiscal stability and discipline contributes, along with other macroeconomic and financial factors, to the emergence of financial or sovereign debt crises.

The absence of adequate institutions, particularly in cases of statist market economies - like Greece-was compensated by the institutional initiatives that were launched in the context of the European integration process; as a result, the domestic model through the "Europeanization" (Featherstone, 2008) process has gradually (but not sufficiently) been enriched with institutions, procedures, and policy packages that promote competition in the economy and reduce macroeconomic imbalances margins. This institutional enrichment in the field of public financial management is decoded in management procedures, rules, and institutions (Rapanos \& Kaplanoglou, 2010). In particular, the fiscal institutions, in theory, may be a core component of the framework of public financial management of each country, having a complementary role in the fiscal consolidation and stabilization effort either through the analysis and evaluation of the fiscal policy or through the involvement in it. This role, however, is that makes the adoption and implementation of the reform in public financial management less popular in cases of statist market economies with a tradition in failing to stabilize their public finances. In such cases, the crucial parameter is the external actors and environment that may create pressure to the reluctant political elite for the promoting of the reform.

\footnotetext{
${ }^{6}$ The study of Rapanos and Kaplanoglou (2010) includes detailed literature associated with this argument.
} 
Greece is a typical case of a statist market economy, which recently obtained "mixed" characteristics during the European integration process. Even though Greece was unable to stabilize its public finances, the establishment of institutions that would ensure fiscal consolidation and discipline was not on the political agenda. Such an institution is a fiscal council. However, EU emphasis on the need of a fiscal council during the effort for the strengthening of economic governance, along with the obligations of Greece in the framework of the EU/ECB/IMF support mechanism adjustment program, led to the "retreat" of the political system's reluctance and to the legislative adoption of the institution. Nonetheless, problems regarding the implementation of the reform were not absent, since the launch of the Fiscal Council remained pending for almost a year and a half. During that period a discussion about the expansion of its competences took place (i.e. evaluation of pre-election platforms) creating concerns about the effectiveness of the major reform.

The analysis of this case study contributes to the broader theoretical discussion concerning the inability of the statist or mixed market economies to establish an environment of fiscal discipline and stability with adequate and efficient institutions. It is a discussion based on the fundamentals of the varieties of capitalism comparative approach and, mainly, on the analytical tools of the public choice theory expanded to the field of fiscal policy and institutions. So, the larger the size and the role of the public sector, the higher the stakes and the cost for the political elite are. The fact that institutional reforms limit significantly the "political" benefits that could derive from public financial management makes political elite reluctant for the promotion of those reforms. The crucial parameter in such cases is the pressure of the external environment, especially in situations of close partnership with significant conditionality. Thus, the analysis of the Fiscal Council's establishment process underlines the significance of the external factor-i.e. the EU and the EU/ECB/IMF support mechanism - concerning the promotion of reforms that the domestic political elite and landscape seemed extremely difficult to implement.

\section{The Greek Economy: From Boom to Crisis and Adjustment}

The Greek economy during the postwar period was marked - as many other western economies - by a strong state involvement in the growth process. It was a time when the state-driven economic policy was characterized by an emphasis on the supply side (along with demand side), fiscal balance, public investment, protection of the industry, anti-inflationary orientation, financial and monetary interventionism, support of import substitution, but also low labor costs, which were favored by an environment of "limited" social demand (Pagoulatos \& Triantopoulos, 2014). The results of this developmental policy were important, as this period, benefiting also from the global economic sentiment was characterized by high growth rates and low unemployment (Kazakos, 2001; Pagoulatos, 2003; Pagoulatos \& Triantopoulos, 2014). However, the reconstruction period, in the early postwar decades, was not accompanied by any substantial upgrading of institutions regarding the market, the welfare state and the bureaucracy of the state. This lack of procedures and mechanisms of redistribution of prosperity in the whole range of society, along with cases of political pressure, led to a gradual increase of the sociopolitical demands, which were inflated during the period of dictatorship following also the impact of intense shocks in the global economy (i.e. oil crises, exchange rate regimes, stagflation, etc.) (Pagoulatos, 2003).

During the 1980s, these sociopolitical demands were reflected in the change of the growth model orientation and in the expansion of the interventionist role of the state in the economy. So, along with the new conditions created after the country's accession to the European Community, the statist economic policy was strengthened and shifted clearly towards the demand side. This policy was characterized, inter alia, by fiscal 
and monetary expansion, salary increases, civil servants recruitments, crowding out of private activity, strong financial interventionism, high cost of funding, nationalization of ailing firms, but also a pseudo-corporatism in the labor market that enabled a strong division between "insiders" (i.e. the public sector, public enterprises, companies in difficulties, banks, etc.) and the "outsiders" (i.e. private sector employees, self-employed, labor excluded groups, undeclared work, etc.) (Kazakos, 1991; Alogoskoufis, 1995; Tsakalotos, 1998; Kazakos, 2001; Pagoulatos, 2003). The shift of the growth model in the 1980s towards the demand side, together with the expansion of the public sector activity, is reflected clearly through the analysis of the components of the domestic product. In particular, consumption expenditure from 75\% of GDP in 1980 reached around 83\% of GDP in 1990, at the expense, mainly, of the share of gross fixed capital formation, which, during the same period, was reduced from 30\% of GDP to $27 \%$ of GDP, and also of the export activity, which declined from 19\% of GDP to levels below $15 \%$ of GDP. At the same time, the public sector significantly expanded its activity, crowding out the private sector: the ratio of general government total expenditure to total expenditure of the private sector, from $18 \%$ on average in the 1960 s and $21 \%$ in the 1970 s, reached $25 \%$ in the $1980 \mathrm{~s}$ - the peak in 1985 was $29.5 \%$ (Pagoulatos \& Triantopoulos, 2014).

The expansion of the public sector was not followed by a corresponding increase in public revenues-due to serious deficiencies of the tax system and tax collection mechanism (i.e. tax exemptions, preferential treatment, corruption and shadow economy, lack of tax consciousness, limited potential of the tax audit mechanisms, etc.). This led to high budget deficits. The average general government deficit in 1980s amounted to approximately $10 \%$ of GDP, increasing public debt from $21.4 \%$ in 1980 to $68.2 \%$ in 1990 and $94.4 \%$ in 1993 - when it included deficits and debts of public companies and general government entities (Figure 1). The large fiscal expansion, however, was not accompanied by high growth rates, as the average growth rate of the 1980s was less than 1\%, while unemployment was not limited, but remained at levels doubled compared to the previous decade (Figure 1). What is clear from the data analysis is a negative relation between fiscal expansion and the unemployment rate, the latter being (usually) limited during periods of increased fiscal deficits and vice versa-reflecting the "statist" nature of the domestic model. At the same time, of course, public debt kept its upward trend, without creating the conditions to enhance the sustainability of the domestic growth and production model (Kazakos, 2001).

The analysis, however, of the series—after 1980 — suggests a close link fiscal policy — and the state of public finances in particular - and the political developments. This link is clearly reflected through the electoral cycle, since, in most cases, significant increases in the budget deficit or deterioration of fiscal planning due to the lack of public financial management institutions are observed in years of national elections (Figure 1). It is a typical phenomenon of poor governance and poor public financial management, which is connected to: (a) the pre-election "loosening" of the tax administration (including also other cases of requirements of the state or public companies towards citizens and businesses), (b) the pre-election or post-election selective (favoring specific groups) public spending, (c) the general extraordinary (one-off) benefits or special tax arrangements (i.e. extensions), (d) the inactivation of the public administration mechanism (i.e. intense politicization of the public sector), (e) the administrative discontinuity that occurs since the administrative positions of responsibility are held by officials who are decisively influenced by the elections (i.e. participation in the pre-election activities, nominations during the election process, post-election changes), and (f) the squandering of public funds (Christodoulakis, 1994; Kazakos, 2001; Skouras \& Christodoulakis, 2011). As underlined by Skouras and Christodoulakis (2011), during the years of elections phenomena such as massive fires or tax fraud 
occur much more often compared to the rest of the period, as a result of the aforementioned characteristics. Thus, once the fiscal discipline and its consequences are not pleasing to the electorate and any financial burden is presented after the election, fiscal expansion, or deterioration seems to be the easy option of the political elite during the election year.

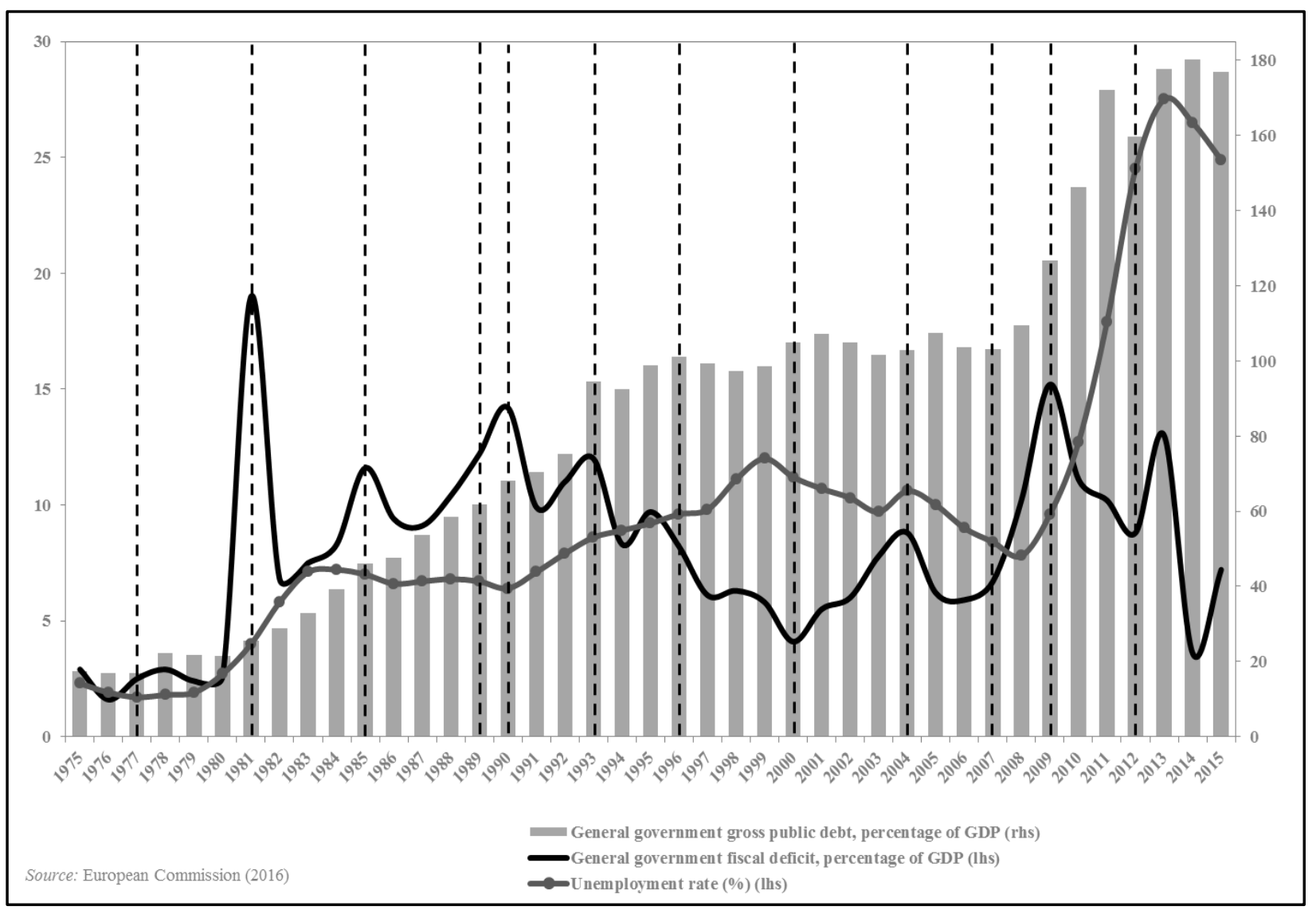

Figure 1. Public finances, unemployment, and elections in Greece (1975-2015). Note. The dashed lines point out the years when the elections took place.

The only exceptions to the above rule are the cases where fiscal discipline and stability were necessary in order to achieve specific goals in the framework of the European integration. The first case took place during the period when Greece followed a convergence route to the "Maastricht criteria" in order to achieve the preconditions for the accession to the EMU. The second was the strict adjustment effort within the EU/ECB/IMF support mechanism, so that the country would avoid a financial collapse that would jeopardize its position in the EMU. However, the fiscal discipline that was observed during the pre-EMU period was not maintained after the achievement of the entrance necessary targets, as after the introduction of the euro, the fiscal expansion returned, reaching its peak during the years of the next elections. It was a new wave of fiscal expansion that reinforced demand side domestic oriented growth model, which since the early 1990s-in an environment of financial liberalization and macroeconomic stabilization-was supported also by the private sector. 


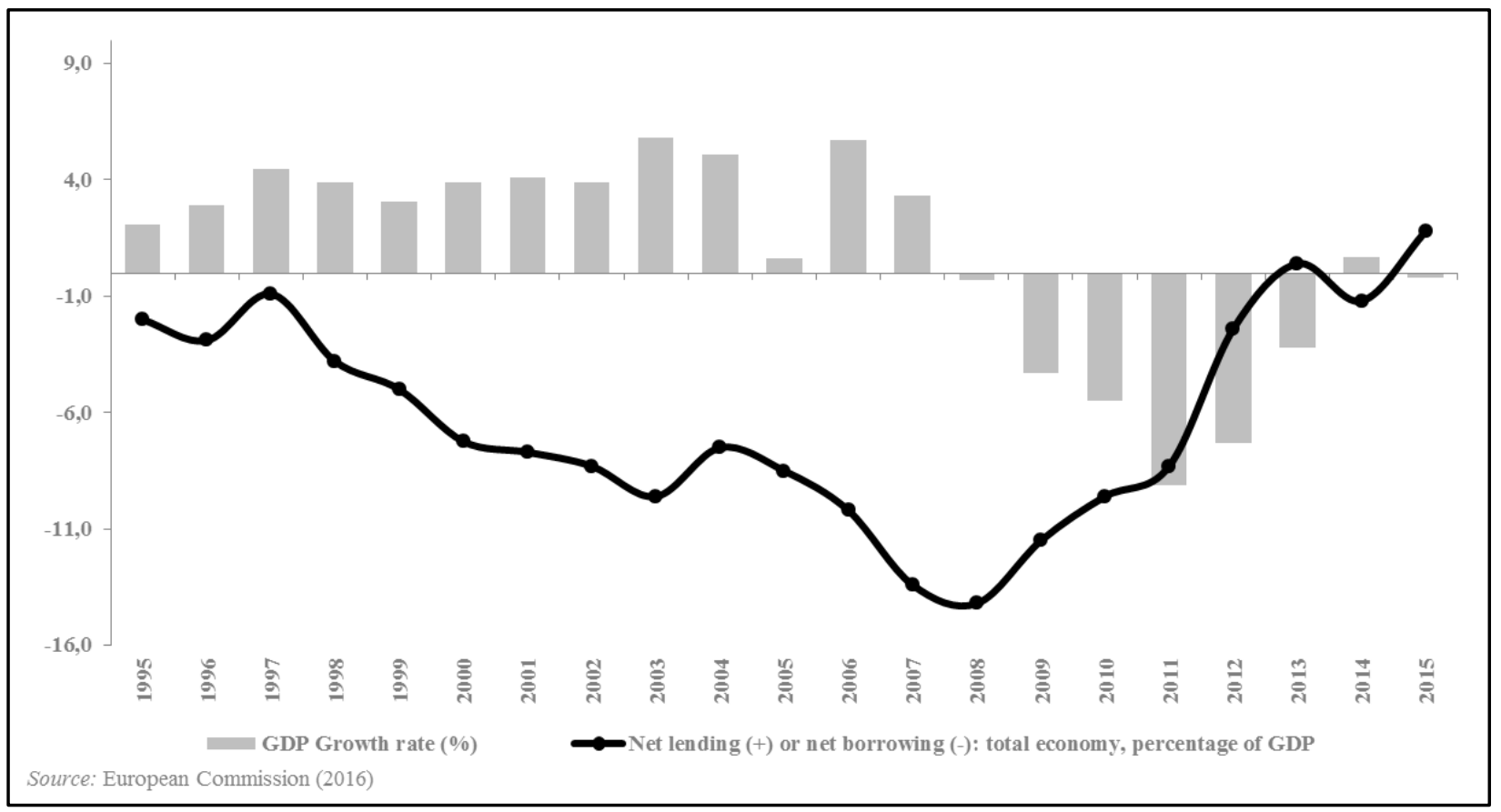

Figure 2. Debt-driven growth in Greece (1995-2015).

Greece's route in the European integration process, from the late 1980s onwards, was characterized by changes in the economy, such as fiscal and monetary stabilization, financial liberalization, gradual openness to the international capital markets (both public and private sector), and greater reduction of funding costs (Pagoulatos, 2003; 2014). Therefore, since the funding of public deficits did not come from domestic savings (as was done in the 1980s through the strong financial intervention), private sector resources and credit expansion, further fueled consumption, resulting in the (gradually) increasing trend of the current account deficit (Vasardani, Brisimis, Papazoglou, Tsaveas, \& Hondroyiannis, 2010; Pagoulatos \& Triantopoulos, 2014); this was of course also due to the focus of the production on non-tradable sectors as well as on sectors of low international competitiveness. The expansion of the consumption oriented domestic production model was strengthened by the fiscal expansion that followed the country's accession to the EMU, since the public sector was now able to borrow at a lower cost through the international capital markets. Therefore, the Greek economy was headed into a path of high growth rates, which, however, were based on the indebtedness of the public and private sector - funded mainly from the international capital markets - and on EU funds. It was a growth path that was the result of, but also dependent on, the indebtedness of the domestic economy (Figure 2).

This debt-driven growth path continued and was further strengthened within the EMU. The current account deficit expanded, underlying the domestic competitiveness weakness, and the extension of public finances continued because of the absence of fiscal institutions. Thus, the 2007/2008 global financial crisis and the shrinkage of liquidity in capital markets that followed found Greece extremely vulnerable, having the biggest problem in terms of "twin" deficits in the euro area (Figure 3). The inability or unwillingness of the capital markets to continue the funding of the country's debt driven growth model-after a series of political decisions and developments - made the "official sector" the only funding source for Greece in order to avoid default. So, in 2010, Greece entered the EU/ECB/IMF support mechanism, which was accompanied by a strict program of economic and fiscal adjustment, based on the logic of "internal devaluation" and frontloaded 
adjustments. The program led to the correction of the "twin deficits" problem until 2015 (Figure 3) in an environment of deep recession, high unemployment, and worsening of the living standards (Giannitsis \& Zografakis, 2015).

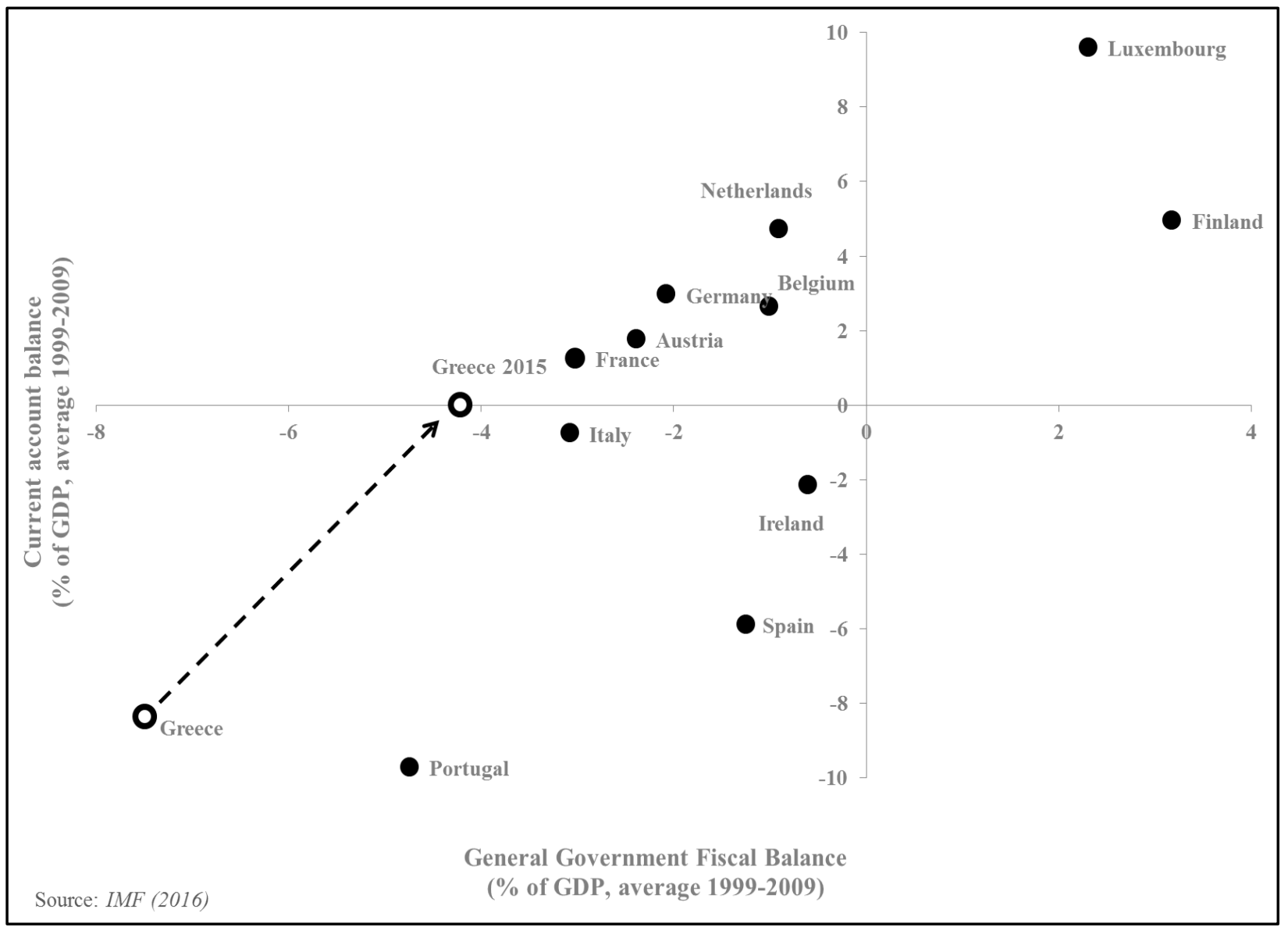

Figure 3. "Twin" deficits/surpluses in the EMU (1999-2009) and adjustment in Greece (2015).

Although the adjustment program included structural reforms and policies for financial stability, the emphasis was on fiscal consolidation, as the country had a short time to reduce the fiscal deficit and achieve primary surpluses in order to gradually reduce its dependence on external funding. Thus, during the period that followed 2010, a large fiscal adjustment took place, leading to a decrease of the fiscal deficit by 11.6 percentage points over the period 2009-2014 (Figure 1). This fiscal adjustment and consolidation effort were accompanied by a series of important structural reforms in the framework of public financial management, following the institutional developments in the EU economic governance. In particular, the most significant structural changes were (a) the creation of a framework on public financial management procedures and rules on a medium-term horizon, (b) the establishment of the independence of the Hellenic Statistical Authority (ELSTAT), (c) the establishment of the Parliamentary Budget Office, (d) the strengthening of the institutional and coordinating role of the General Accounting Office and the establishment of Accounting Officers in every Ministry, (e) the restructuring and upgrading of the fiscal audit system, (f) the establishment of a framework of fiscal rules and monitoring and adjustment procedures for all general government entities, (g) the establishment of an fiscal autonomy observatory for the local government, (h) the implementation of a registry of 
commitments mechanism for controlling general government expenditures, and (i) the harmonization and enrichment of the framework of public financial management with the rules, procedures, terms, and corrective mechanisms proposed by the new EMU economic governance environment. The last institutional initiative included the establishment of the Fiscal Council.

The aforementioned institutional and structural measures were necessary for the significant fiscal adjustment that took place during 2010-2014. However, after the first positive fiscal achievements, the commitment of the political elite to fiscal discipline was abandoned. So, in another elections year-as was the case after the accession in the EMU - the fiscal adjustment effort was "loosened" and the institutional settings were not strictly followed ${ }^{7}$ (Figure 1). It appears, therefore, that despite the large fiscal effort, during the period, the institutional framework of public financial management did not include the components that would limit the discretion of the political elite regarding the annual and medium-term fiscal planning. This picture underlines the need for further strengthening of the elements of the public financial management framework. A crucial element is the Fiscal Council.

\section{Analysis on the Hellenic Fiscal Council}

The introduction of fiscal council as an institution that secures fiscal stability and discipline (either as an independent institution, a parliamentary body, or an administrative institution, etc.) has been considerably increased during the recent years in Europe. The increase was the result of the efforts, mainly on behalf of the euro area, to enhance the EU economic governance environment after the turbulence that followed the 2007/2008 global financial crisis. However, in several cases, fiscal councils or other independent fiscal authorities had been established several decades ago. In Europe, the first one was established in the Netherlands (1947) and followed by Denmark (1962), Germany (1963), and Belgium (1989) - the majority, however, of the member-states established fiscal institutions recently (European Commission, 2012; European Central Bank, 2013; European Commission, 2013; Debrun \& Kinda, 2014). The range of the fiscal council competences varies, depending on the fiscal conditions but also on the history of each economy and the institutional tradition of each country, as well as on the intentions of the political elites, resulted in differences in their institutional status, their objectives, their means to achieve the objectives and the degree of their intervention in fiscal policy.

In particular, the Fiscal Council is a concrete (depending on the degree of independence) institution, within the broader context of fiscal policy planning and making, which mainly (a) monitors and evaluates fiscal policy, focusing on the harmonization of the annual and medium-term budgetary targets, (b) analyzes the reliability of state budget estimations and the medium-term planning in terms of basic components (i.e. public expenditure, public revenues, fiscal balance, primary balance, etc.), proceeding to corresponding estimations, (c) formulates and evaluates forecasts for the macroeconomic conditions, (d) assesses the long-term sustainability of public finances and, in particular, public debt, (e) evaluates measures and policies and estimates cost implications of the planned and implemented fiscal measures, (g) conducts public spending reviews to ensure public expenditures' efficiency, (h) informs society about the situation and prospects of public finances through public statements, and (i) provides recommendations and possible proposals for the planned and/or followed fiscal and economic policy (Hagemann, 2010; Calmfors \& Wren-Lewis, 2011; IMF, 2013a). The efficiency, of

\footnotetext{
${ }^{7}$ In 2015 (and in 2016), the Ministry of Finance did not announce and submit—as had to do—a Medium Term Fiscal Strategy.
} 
course, of the fiscal council is largely based on its institutional and functional independence which should be safeguarded at all stages (not only at its establishment). As stated in the empirical analysis of Debrun and Kinda (2014), the "well-designed" fiscal councils are associated with better fiscal performance and macroeconomic and fiscal projections, emphasizing that key factors on this are the operational independence of the institution (i.e. no political interference), the provision of budgetary forecasts, the strong presence in the public debate, and the monitoring of the alignment with the fiscal rules.

In Greece, the Fiscal Council was established in the summer of 2014 by the law 4270 and is planned to: (a) evaluate the macroeconomic forecasts on which the fiscal strategy is based, (b) monitor the compliance with the fiscal rules and make assessments regarding their implementation, (c) assess the fiscal estimations in relation to the medium-term fiscal strategy, (d) evaluate both the fiscal objectives and the outcome in relation to the medium-term fiscal strategy, and (e) analyze the macroeconomic and fiscal developments affecting growth, employment, and social budget.

Regarding its institutional status, the Fiscal Council (a) is an independent administrative authority enjoying operational independence and not subject to control by government institutions (i.e. the financial statements are subject to the Court of Auditors' control), (b) is governed by specific confidentiality procedures, avoiding conflicts of interest and guaranteeing impartiality, (c) is characterized by transparency and information disclosure, and (d) is subject to external evaluation at least every four years. In addition, the institutional status of the Fiscal Council is ensured by both the selection process and by the way of renewal of the five-member board of directors of the Fiscal Council, which is planned to be staffed by high-level academics and professionals, of which only two of them may have take political positions in the past - at least four years before. The selection process for board members includes an international open call, an initial selection process by a high-level committee, ${ }^{8}$ a further selection process conducted by the Council of Ministers, and an approval by the Special Permanent Committee on Institutions and Transparency of the Parliament. At the same time, the renewal of the mandate of board members takes place in different periods in time, in order to further "protect" the membership selection process from the "limitations" of the political cycle and to ensure administrative continuity for the intensive work, it is expected to carry out.

The establishment, however, of the Fiscal Council did not receive political elite's broad support, as it was not supported by the opposition political parties — especially the largest opposition party-during the parliamentary process, while there were negative comments on behalf of the governmental parties. In addition, although the government promoted the law's adoption - under the EU/ECB/IMF support mechanism and the European obligations - it did not directly proceed — as planned — to its establishment. In particular, even though the establishment of the Fiscal Council was expected — by law — to take place in the summer of 2014, the board of directors was appointed in the second half of 2015 and until the first half of 2016 the institution was still not in full operation.

The political elite did not seem prepared to complete a major institutional reform which, at least theoretically, would strengthen fiscal discipline, but would also limit the strong political discretion in fiscal policy. However, as in other similar occasions, domestic political reluctance was bent by the abroad conditionality framework. In particular, the implementation of such an institutional reform became mandatory

\footnotetext{
8 The members of the Committee are the Minister of Finance, the Governor of the Bank of Greece, and the President of the Court of Auditors.
} 
for the political elite due to its inclusion in the prerequisites of the third economic adjustment program, ${ }^{9}$ in the framework of the EU/ECB/IMF support mechanism. So, in October 2015, the recruitment procedure of the Fiscal Council's board of editors proceeded. Then, under the "pressure" of the EU/ECB/IMF support mechanism conditionality, the establishment of the Fiscal Council appeared to enjoy greater political support, as its implementation in 2015 was promoted by the political parties (now in government) that in 2014 had expressed their strong objection. However, as already mentioned, until the second quarter of 2016, the institution was not in full operation, as the recruitment process was based on internal movements of public sector's manpower and not on new hiring of experts.

In 2015, the "restart" of the reform was accompanied by a debate. In particular, the Ministry of Finance expressed its intention to enhance the Fiscal Council's competences with the evaluation of pre-election economic platforms of the political parties. ${ }^{10}$ Substantially, it was an idea that was initially brought up in the summer of 2014 during the discussion on the establishment of the institution. In particular, the topic was discussed by the (previous) government in 2014 and, especially, by the Alternate Finance Minister, whilst during the parliamentary proceedings, the idea was also proposed by the Centre for Planning and Economic Research (KEPE). As long as the idea was not supported by the political elite, it did not manage to go beyond the field of theoretical discussion at the time, while technical staff of the EU/ECB/IMF support mechanism were also reluctant to the idea, underlying that Greece was not institutionally mature for such a reform and that undertaking such a competence was very likely to undermine the basic task of the institution. The fact, however, that differentiates the circumstances after 2015 compared to the previous year is that the Fiscal Council has a broad support of the political system. This allows, at least, the re-opening of the discussion on the scenario.

\section{Discussion on the Evaluation of the Pre-election Economic Platforms}

Along with the basic competences, fiscal council can be responsible —on request - for the evaluation of the pre-election economic platforms of political parties, on request. This institutional setting is based on the approach that supports the creation of such a platform in order to contribute to the harmonization of pre-election political discourse and program with the actual state of public finances and the real economy. The most important dimension, however, is that such an institutional setting enhances democracy by providing the necessary information to the citizens during the electoral and political process, as they are able to know the potential impact of the economic policies among which they are asked to choose through their vote.

The most typical case is that of the Netherlands, and more particularly, the Bureau for Economic Policy Analysis (CPB). Also, such institutional settings are also detected in the cases of the Congressional Budget Office in the United States and the Institute for Fiscal Studies in the United Kingdom, while similar cases can be found in some other European economies, without, however, being in the range and scope of the Dutch institution. In particular, the CPB started evaluating the pre-election economic platforms of political parties in 1986 and the number of parties involved has increased since then (due to competition in proving that proposals are realistic and effective). Moreover, the requirements of citizens concerning the analysis of the results have increased and the range of fields covered by the evaluation has also been extended (Bos \& Tuelings, 2011). In

\footnotetext{
9 Greece's Memorandum of Understanding with the European Commission for the third economic policy program is available from http://ec.europa.eu/economy_finance/assistance_eu_ms/greek_loan_facility/pdf/01_mou_20150811_en.pdf.

10 The idea was included in the program that the Minister of Finance Yanis Varoufakis submitted to the EU/ECB/IMF partners during the negotiation process of the first half of 2015.
} 
particular, the fields of analysis, during the 2010 elections, are: (a) the direct impact on the budget, (b) indirect effects on the budget, labor market and GDP, (c) the long-term impact on employment and GDP, (d) the impact on purchasing power in different household types, (e) the long-term impact on the budget, ( $\mathrm{g}$ ) the analysis of effects on specific sectors (health, infrastructure, education, etc.), and (h) the analysis of the effects on specific sectors based on welfare criteria (Bos \& Tuelings, 2011).

In the case of Greece, where the harmonization of the electoral cycle with fiscal deterioration is the "regularity" and the inability to maintain financial stability is significant, the possibility of assigning to the Fiscal Council a technocratic, credible, impartial, and independent evaluation of the pre-election economic programs is of special importance. This is an important reform with wider political and economic impact and effect on the quality of democracy and elections in the country. However, taking into account the peculiarities of the domestic political economy and institutional tradition in Greece, six prerequisites needed to be met, in order for such a reform to be successful and produce the expected results (Triantopoulos, 2015).

The first prerequisite is institutional independence. The institutional framework for the establishment, the staff and the competences of the Fiscal Council—based on law 4270/2014 - seem to ensure its institutional independence. The fact, however, that the Fiscal Council will take on a responsibility that has significant impact on political developments is expected to inflate the political pressure on it and its staff. Such an increase of political pressure can seriously affect the effectiveness of the original purpose of the Fiscal Council. ${ }^{11}$ Therefore, it is necessary for the government to ensure, when and where needed, the institutional independence of the institution, focusing on rigorous - without exceptions - implementation of every dimension of its institutional status and addressing any gap that may occur after the enrichment with the new responsibilities. The emphasis on the institutional independency is crucial in order to prevent the emergence of doubts - from the society - regarding the institutional status of the Fiscal Council (Triantopoulos, 2015). In this context, the possibility of increasing the required parliamentary majority in the Special Permanent Committee on Institutions and Transparency of the Parliament during the appointment of the board of directors could be considered.

Along with institutional, a crucial prerequisite is the "political" independence. The assignment of the evaluation of pre-election economic programs of political parties requires further "protection" of the Fiscal Council from political pressures. Initially, the involvement of politicians in the board of directors of the Fiscal Council should be excluded in order for its evaluation to become acceptable and credible. In particular, if people involved in politics participate in the Fiscal Council's board, even if their evaluations are far from biased, it will become rather difficult to gain the acceptance of the society as a whole, undermining the very substance of the institution (Triantopoulos, 2015). Therefore, it would be useful to amend law 4270/2014 which allows the involvement of members that have a political background - even after the end of a four-year period with no political involvement. In parallel, it is also important to make sure that no stronger involvement of the Parliament occurs, apart from what has already been stipulated in the law. This second condition is "separated" from the institutional independence so as to further emphasize on the need for "protection" of the institution that assesses political parties' programs from possible political interference.

The third prerequisite is functional independence. In parallel and following the provisions of law 4270/2014, it is crucial for the Fiscal Council to have — on time - the adequate facilities and human resources in

11 This was also the anxiety of the technical assistance team of the EU/ECB/IMF support mechanism during the 2014 consultation. 
order to function independently and respond, technically and scientifically, to the competences assigned. Once responsibilities are expanded to the pre-election programs' evaluation, the functional capacity should also be expanded by increasing the quantity and quality of its scientific staff (Nitsi, 2014), and by developing cooperation and networks with reliable other institutions.

The fourth necessary condition is the achievement of broad political acceptance of the Fiscal Council's new competences. In particular, the approval of the political parties on the assignment of the pre-election programs' evaluation to the Fiscal Council seems like a prerequisite for the society to accept the institutional setting. On the contrary, if there is no broad political approval, it is highly probable that this institutional initiative will be the subject of political debate, weakening the venture before it even begins to operate. And, of course, such a weakening does not concern solely the dimension of the assessment of election programs, but could expand to all aspects of the Fiscal Council activities, significantly affecting the original purpose of its establishment (Triantopoulos, 2015). In 2014, as revealed during the parliamentary consultation, there was not enough political consensus even on the necessity of the Fiscal Council's establishment. Therefore, it was difficult at that time to discuss the assignment of a new and significant responsibility to the institution. Now that the institution enjoys a broader approval of the political elite, it is critical to reconsider the intentions of the main political parties for such an assignment, in order to gain the broad political acceptance that is needed before proceeding.

A fifth prerequisite is a necessary "adjustment period" before the institutional setting. In particular, the good reputation of a new institution is being built through the efficiency of its work within a reasonable period of time. This also applies to the Fiscal Council, which should first demonstrate its efficiency on its basic role in the fiscal policy framework in order to gradually forge its reputation as an institution and gain the acceptance of the society. ${ }^{12}$ It is important, therefore, for the Fiscal Council to build an adequate reputation in terms of credibility, impartiality, and effectiveness, before it takes over the evaluation of pre-election platforms. So, a reasonable "adjustment period" is necessary — as in the case of other European economies - before the Fiscal Council starts to evaluate the political parties' pre-election programs, so that the good reputation will affect positively these evaluations as well.

The sixth prerequisite, which is more technical, refers to the clarity of rules and evaluations procedures. In particular, it is important that the evaluation of the pre-election economic programs is made by the Fiscal Council through transparent and standardized procedures that are based on clear rules, in order to further forge the credibility of the resulting evaluations. These rules, according to Bos and Tuelings (2011), must focus on the independence from the political process, the good communication among political parties and the Fiscal Council and the quality and objectivity of the Fiscal Council evaluations. Thus, compliance to these rules further ensures the credibility of Fiscal Council's work on both the political elite and the society.

\section{Conclusions}

Greece is a typical statist - mixed - market economy with a tradition on unstable public finances and lack of adequate institutions. It is a case of a political economy where the institutions and the rules of public financial management are approached with reluctance by the political elite, as the short-term political costs seemed to outweigh the medium-term economic and developmental benefits from macroeconomic and financial

12 About the importance of reputation see IMF (2013b). 
stability. The establishment of a Fiscal Council is included in this context, as it is an institution that could contribute - under the institutional and functional independency hypothesis - to fiscal discipline and stability. The opportunity cost - because of the loss of fiscal discretion - of the political elite and, by extension, the political reluctance against such a reform, made the establishment feasible only after the pressure of an external factor, as in many other occasions of institutional reforms.

Thus, the adoption and establishment of the Fiscal Council in Greece were the result of the obligations occurring from the strengthening of economic governance in the EMU and of the pressures under the EU/ECB/IMF support mechanism, while the political elite, even after the adoption of the law, did not seem strongly committed to completing the reform. However, the pressing environment that was formed during the introduction of the third economic adjustment program contributed to the mitigation of several political reservations regarding the need for such an institution, making the establishment of the Fiscal Council acceptable from the vast majority of the political parties.

The restart of the reform process in 2015 , combined with the usual enthusiasm that occurs during the establishment a new institution, was accompanied by the discussion about the enrichment of the institution's competences, focusing on the evaluation of pre-election programs of political parties. It was a debate that was opened in 2014, but did not lead to any institutional change. However, it remained a scenario for further discussion.

The evaluation of pre-election economic programs or proposals of economic policy of the political parties, even if it seems ultra-difficult for the case of Greece, should not be set aside as unachievable. On the contrary, given the aforementioned prerequisites and conditions, Greece can gradually enter a phase where the political parties - in an environment of special political competition - would consider submitting their pre-election economic programs or economic policy proposals for evaluation by a credible, impartial, and independent institution, such as the Fiscal Council. Up to this point, of course, the process is very difficult and long, and the conditions described above-institutional independence, political independence, functional independence, broad political acceptance, "adjustment period", and clarity of rules and evaluation procedures - should be ensured in order to enable the Fiscal Council to undertake this significant role. Taking, however, into account the fact that Greece has entered a coalition government phase, the new task of the Fiscal Council will be very useful, as the evaluations of pre-election platforms could actually become the foundation for further political coalitions. In any case, a successful introduction of these evaluations by the Fiscal Council will have an important contribution to the quality of democracy. So, even though the evaluation of pre-election economic programs seems ultra-difficult for the case of Greece, it should not be set aside as unachievable in the long run.

\section{References}

Alogoskoufis, G. (1995). The two faces of Janus: Institutions, policy regimes and macroeconomic performance in Greece. Economic Policy, 10(20), 147-192.

Berger, S. (1981). Organizing interests in Western Europe. Cambridge: Cambridge University Press.

Bos, F., \& Tuelings, C. (2011). Evaluating election platforms: A task for fiscal councils? Scope and rules of the game in view of 25 years of Dutch practice. Social Science Research Network. Retrieved from http://ssrn.com/abstract=1864564

Buchanan, M. J. (1987). The constitution of economic policy. The American Economic Review, 77(3), 243-250.

Calmfors, L., \& Wren-Lewis, S. (2011). What should fiscal councils do? Economic Policy, 26(68), 649-695.

Chandler, A. (1977). The visible hand: The managerial revolution in American business. Cambridge, MA: Harvard University Press. 
Christodoulakis, N. (1994). Tax collection lags and the revenue-maximizing inflation. Empirical Economics, 19(3), $329-342$.

Debrun, X., \& Kinda, T. (2014). Strengthening post-crisis fiscal credibility: Fiscal councils on the rise-The new dataset. $I M F$ Working Paper, WP/14/58.

European Central Bank. (2013). The importance and effectiveness of national fiscal frameworks in the EU. ECB Monthly Bulletin, February, 73-88.

European Commission. (2012). Fiscal frameworks across member states: Commission services country fiches from the 2011 EPC peer review. European Economy, Occasional Papers, No. 91.

European Commission. (2013). Fiscal frameworks in the European Union: Commission services country factsheets for the autumn 2013 peer review. European Economy, Occasional Papers, No. 168.

Featherstone, K. (2008). Varieties of capitalism and the Greek case: Explaining the constraints of domestic reform? LSE GreeSE Papers, No. 11.

Giannitsis, T., \& Zografakis, S. (2015). Greece: Solidarity and adjustment in times of crisis. Macroeconomic Policy Institute (IMK) Study, No. 38. Retrieved from http://www.boeckler.de/pdf/p_imk_study_38_2015.pdf

Goldthorpe, J. (1984). (Ed.). Order and conflict in contemporary capitalism. Oxford: Clarendon Press.

Hagemann, R. (2010). Improving fiscal performance through fiscal councils. OECD Economics Department Working Papers, No. 829.

Hall, P., \& Gingerich, D. (2004). Varieties of capitalism and institutional complementarities in the macro-economy. MPIfG Discussion Papers, No. 04/05.

Hall, P., \& Soskice, D. (Eds.), (2001). Varieties of capitalism. The institutional foundations of comparative advantage. Oxford: Oxford University Press.

Hancke, B., Rhodes, M., \& Thatcher, M. (Eds.), (2007). Beyond varieties of capitalism: Conflict, contradictions and complementarities in the European economy. Oxford: Oxford University Press.

International Monetary Fund (IMF). (2013a). The functions and impact of fiscal councils. IMF Policy Paper. Retrieved from https://www.imf.org/external/np/pp/eng/2013/071613.pdf

International Monetary Fund (IMF). (2013b). Case studies of fiscal councils: Functions and impact. IMF Policy Paper. Retrieved from https://www.imf.org/external/np/pp/eng/2013/071613a.pdf

Jackson, G., \& Deeg, R. (2006). How many varieties of capitalism? Comparing the comparative institutional analyses of capitalist diversity. MPIFG Discussion Papers, No. 06/02.

Kazakos, P. (1991). Greece between adjustment and marginalization (in Greek). Athens: Diatton Publishing.

Kazakos, P. (2001). Between state and market: Economy and economic policy in post-war Greece (1944-2000) (in Greek). Athens: Patakis Publishing.

Kazakos, P. (2006). Explaining society: Introduction to methods and technics (in Greek). Athens: Patakis Publishing.

Kroszner, R., \& Strahan, P. (2000). Obstacles to optimal policy: The interplay of politics and economics in shaping bank supervision and regulation reforms. NBER Working Papers, No. 7582.

Lowndes, V. (2002). The institutional approach. In D. Marsh and G. Stoker (Eds.), Theory and methods in political science (pp. 90-108). Houndmills: Palgrave.

Molina, O., \& Rhodes, M. (2007). The political economy of adjustment in mixed market economies: A study of Spain and Italy. In B. Hancke, M. Rhodes, and M. Thatcher (Eds.), Beyond varieties of capitalism: Conflict, contradictions and complementarities in the European economy (pp. 223-254). Oxford: Oxford University Press.

Nitsi, E. (2014). Frameworks of ooperation, competences and objectives of the European fiscal councils: Proposals for the new established Hellenic Fiscal Council (in Greek). Greek Economy, 8, 30-38.

North, D. (2000). Big-bang transformations of economic systems: An introductory note. Journal of Institutional and Theoretical Economics, 156(1), 3-8.

Pagoulatos, G. (2003). Greece's new political economy. State, finance and growth from postwar to EMU. Houndmills: Palgrave Macmillan.

Pagoulatos, G. (2014). State-driven in boom and in bust: Structural limitations of financial power in Greece. Government and Opposition, 49(3), 452-482.

Pagoulatos, G., \& Triantopoulos, C. (2009). The return of the Greek patient: Greece and the 2008 global financial crisis. South European Society and Politics, 14(1), 35-54.

Pagoulatos, G., \& Triantopoulos, C. (2014). Growth strategy and welfare reform in Greece. Paper presented at the Workshop on "National Growth Strategies and Welfare State Reform", Sciences Po, Paris, 11-12/12/2014. 
Rapanos, V., \& Kaplanoglou, G. (2010). Independent fiscal councils and their potential role in Greece (in Greek). Economic Bulletin of the Bank of Greece, 33, 7-22.

Schmidt, V. (2002). The futures of European capitalism. Oxford: Oxford University Press.

Schmidt, V. (2003). French capitalism transformed, yet still a third variety of capitalism. Economy and Society, 32(4), 526-554.

Schmitter, P., \& Lehmbruch, G. (Eds.), (1979). Trends toward corporatist intermediation. Beverly Hills, CA: Sage Publications.

Shonfield, A. (1965). Modern capitalism: The changing balance of public and private power. Oxford: Oxford University Press.

Skouras, S. \& Christodoulakis, N. (2011). Electoral misgovernance cycles: Evidence from wildfires and tax evasion in Greece and elsewhere. LSE GreeSE Papers, No. 47.

Triantopoulos, C. (2014). European financial markets and supervisory framework: A political economy view (in Greek) (Ph.D. Thesis). Department of International and European Economic Studies, Athens University of Economics and Business.

Triantopoulos, C. (2015). Fiscal council and evaluation of political parties' economic programs (in Greek). ELIAMEP/Crisis Observatory Policy Papers, No. 28.

Tsakalotos, E. (1998). The political economy of social democratic economic policies: The PASOK experiment in Greece. Oxford Review of Economic Policy, 14(1), 114-138.

Vasardani, M., Brisimis, S., Papazoglou, C., Tsaveas, N., \& Hondroyiannis, G. (2010). Determinants and sustainability of the current account balance in periods of structural reforms (in Greek). In G. Economou, I. Sabethai, and G. Simigiannis (Eds.), Current account balance in Greece (pp. 263-287). Athens: Bank of Greece.

Zysman, J. (1983). Governments, markets and growth. Financial systems and the politics of industrial change. Ithaca, NY: Cornall University Press. 